\title{
Sari Oneng Parakansalak Gamelan Tuning System and Its Comparison with Machjar's Theory
}

\author{
Ega Fausta \\ Magister Program Indonesia Institute of Arts Surakarta \\ Jl. Ki Hadjar Dewantara 19 Surakarta 57126, Indoneisa, (0271) 647658, Email. direct@isi-ska.ac.id \\ egafaustaa@gmail.com
}

\section{ARTICLE INFO}

Article histor

Received 2019-03-31

Revised 2019-06-02

Accepted 2019-05-24

Keywords:

Sari Oneng Parakansalak Gamelan, Laras Pelog

Laras Theory of R.M.A.

Koesoemadinata

\section{ABSTRACT}

The research of measuring laras of Sari Oneng Parakansalak gamelan uses convergent parallel mixed methods. It attempts to find out the interval arrangement, which forms a scheme called laras system. This research give a provides clues about the existence of pelog gamelan in Sunda which is still debated until nowadays, which becomes the main reason why the writer is interested to measure the laras of Sari Oneng Parakansalak gamelan. In this research, laras theory of R.M.A. Koesoemadinata is used as the comparison to investigate what kind of laras is the laras scheme resulted from Sari Oneng Parakansalak gamelan's interval arrangement. The result of this research is in form of persentation numbers which reveals the similarity between laras system of Sari Oneng Parakansalak gamelan and laras theory of R.M.A. Koesoemadinata. Besides giving a conclusion about the conformity between laras theory of R.M.A. Koesoemadinata and the fact found in the field, this research also informs about Sundanese pélog gamelan, which its existence is still hesitated/questioned by some Sundanese society. This study uses Da Tuner Lite which is validated with Korg Orchestral Tuner (OT-12) as the measuring instrument. The data of each waditra and the average of whole measured waditra are used to analyze the data of measurement result. From those two techniques, it can be detected that there are some waditra which are inappropriate to be used as samples. Therefore, the result of this study is taken from three waditra saron which indicates that Sari Oneng Parakansalak gamelan tends to have laras pélog djawar with its $87,19 \%$ of similarity. That result can also reveal that pélog gamelan really exists in Sundanese culture, proven by Sari Oneng Parakansalak gamelan which is made in Sumedang in 1825 .

This is an open access article under the CC-BY-SA license.

\section{Introduction}

Sari Oneng Parakansalak Gamelan is one of the oldest pélog gamelan in West Java. According to the data from Prabu Geusan Ulun Museum, it was made around 1825 in Sumedang, which at that time became the cultural center in West Java. If we examine the description board like in Figure 2 which is placed in front of the gamelan like Figure 1, we may discover a brief interesting story which rarely known by most people.

Sari Oneng Parakansalak Gamelan, as one of the precious cultural heritage, has several underlying reasons to be chosen as an interesting object to be observed. One of the main reasons is that even though it is old enough, it still can be seen and can be used especially in Prabu Geusan Ulun Museum in Sumedang. 


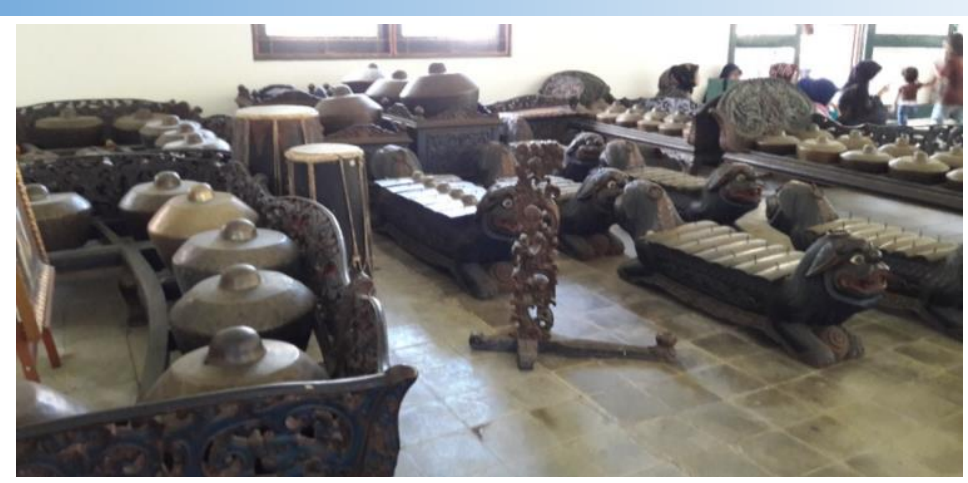

Fig. 1. Gamelan Sari Oneng Ansamble

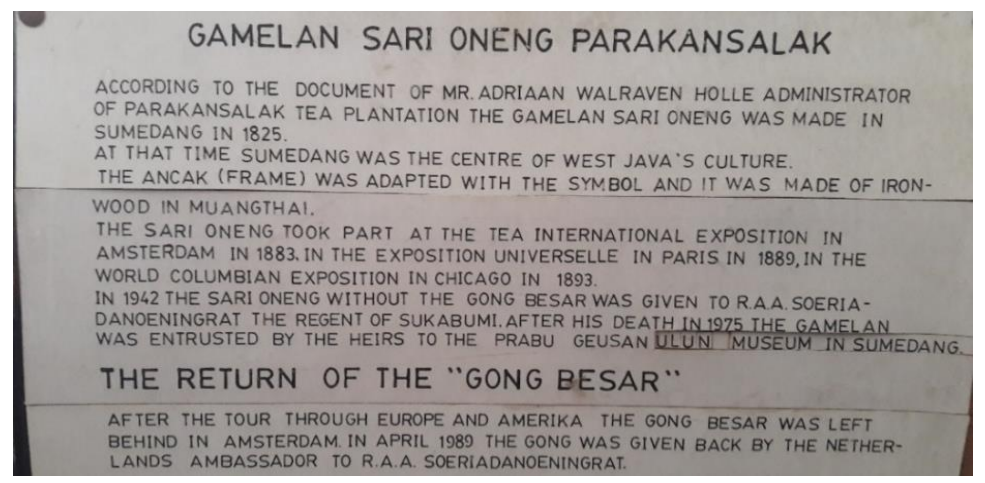

Fig. 2. Description Board of Gamelan Sari Oneng Parakansalak

Therefore, it can provide information related to the existence of pélog gamelan in Sundanese area which is still be questioned until nowadays. Most of people believe in an assumption that a laras pélog exists in Sundanese is laras pélog degung, which is neither the original laras pélog like one exists and develops in Javanese, nor laras pélog according to the theory from R. M. A. Koesoemadinata. The difference in addressing the terms of laras pélog with laras pélog degung is in line with an article written by Nano S., who states that Koko Koswara is one of the artists who has different opinion about addressing the terms of laras pélog and laras pélog degung (Nano S, n.d: $10)$.

On the other hand, laras theory by R. M. A. Koesoemadinata is a theory which discuss about laras in Sundanese karawitan that is still used among the society and academic field especially in SMKN 10 Bandung and in ISBI (Institut Seni Budaya Indonesia) Bandung. Some studies have been conducted by researchers in attempt to answer questions and critics by foreign musician who assume that there are several weaknesses in that theory in relation with the appropriateness between the theory itself and reality in the field (Hermawan 2001: 2).

There are several studies that have been conducted related to the topic. Deni Hermawan in 1999 conducted a related study which focused on laras saléndro, degung and madenda. This study measured laras in kacapi indung (waditra used in tembang Sunda cianjuran) that was played by several artists. The result of the study showed that musical scale according to the theory from R. M. A. Koesoemadinata is not completely suitable because the interval of similarity is far from the ideal one (Hermawan 2001). The inappropriateness between laras theory by R. M. A. Koesoemadinata with the actual practice in the field caused by several factors. One of them is the difference of laras feeling from each artist.

The next study is one conducted by Heri Herdini which reveals that there is no laras saléndro padantara because the result of the study shows that laras saléndro scheme is bèdantara, even though bèdantara which is addressed by him is different with bèdantara scheme according to R. M. A. Koesoemadinata. It concludes that laras degung and madenda are not derivative from laras saléndro (Herdini 2004).

The results of some studies mentioned above indicate different conclusions, and thus make the writer more interested to investigate about how is the laras concept in Sundanese karawitan in certain, whether it is still relevant with Machjar's laras theory, which is still widely used until now 
for both practical and academic purposes. Besides, those studies mentioned earlier indicate that they specifically focused on laras saléndro, degung and madenda. Therefore, in this research, the writer investigate the laras system in Sari Oneng Parakansalak gamelan, which is assumed as laras pélog gamelan, and then compare it with laras pélog theory by Machjar.

A general description about several interesting topics mentioned above, especially one which is related to Sari Oneng Parakansalak gamelan and laras theory by Machjar, is actually can be investigated from various aspects. However, considering the limited time, this study is only focused on the laras system and then it will be calculated in order to find out its similarity level with laras theory by R.M.A. Koesoemadinta, which in turn can determine to which laras this gamelan includes to.

\section{Method}

In order to carry out scientific research, steps must be taken carefully in order to get accurate results. To answer the research questions, the appropriate method is needed, so that the aim of this study can be achieved. This research uses convergent parallel mixed methods, which is a method where the researcher gather or combine both quantitative and qualitative data, so that they can provide the analysis of the research problem comprehensively (Creswell, 2016: 21). Furthermore, Cresswell defines a parallel convergent mixed method in two ways. First, as a research phase from the start the researcher collects both qualitative data and quantitative data, analyzes them separately, and then compares the results to find out the results confirm or not confirm each other (Creswell, 2016: 293). Second, as a form of mixed method design, researchers gather or combine both quantitative and qualitative data in order to provide a comprehensive analysis of research problems (Creswell John W 2018: 21).

Generally, the design of a convergent parallel mixed method consists of four main stages which include (1) Data collection; (2) Analysis of data; (3) Interpretation, and Validation. In the measurements activity, this study uses Da Tuner Lite application which is validated with Korg Orchestral Tuner (OT-12) as the measuring instrument.

\section{Results and Discussion}

\subsection{Definition of Laras and Machjar's Theoritical Laras Pelog}

According to R.M.A Koesoemadinata (Koesoemadinata 1969: 16-17) laras comes from the word raras $(\mathrm{ra}=\mathrm{sun}=$ beautiful, ras=feel). It is a set of tones which has regular interval on every gembyang and in line with art-feel. From the definition above, we know that the main thing in laras Sunda is interval which also know as scale. The word scale properly means ladder, because the notes thus sounded gives us the sensation of ascending by definite distances (Ellis 1885: 486). Writing laras in Sundanese Karawitan (Sundanese musical scale) uses a notation system which is symbolized with a number notation, such as 1,2,3, 4, and 5 which is read as da (1), mi (2), na (3), ti (4), and la (5).

Furthermore, R. M. A. Koesoemadinata states that, rakitan pèlog in form of gamelan its kempyung interval is $666 \frac{2}{3}$ sen, which is obviously different with western musical scale, kempyung $^{1}$, which is 700 sen (Koesoemadinata 1969: 52). Rakitan pèlog, according to R. M. A. Koesoemadinata consists of nine notes on each gembyang which have the same interval that is $\frac{1}{9}$ gembyang $\left(133 \frac{1}{3}\right)$. From nine notes on rakitan pèlog, five notes become murdaswara (lulugu voice). They are tones $1(\mathrm{da}), 2(\mathrm{mi}), 3(\mathrm{na}), 4(\mathrm{ti}), 5(\mathrm{la})$ and the other four tones which are 5+ (leu), $2+(m e u), 3-(n i)$, and 1- (di) become uparénggaswara (papaés voice).

On laras pèlog hit instruments or tatabuhan each gembyang has seven raras in form of wilahan and penclon. The seven raras are deret kempyung or banjar kempyung such as shown in Figure 3 follow:

\footnotetext{
${ }^{1}$ The used of kempyung word in the Western Music tuning system as the R. M. A. Koesoemadinata opinion actually can't find and never known in the western musical dictionary.
} 


$$
\begin{aligned}
& \text { Pèlog } 666 \frac{2}{3} \text { Pangasih } 666 \frac{2}{3} \text { Lima } 666 \frac{2}{3} \text { Gulu } 666 \frac{2}{3} \text { Nem } 666 \frac{2}{3} \text { Dada } 666 \frac{2}{3} \text { Barang } \\
& \begin{array}{lllllll}
\mathrm{Ni} & \mathrm{La} & \mathrm{Mi} & \mathrm{Ti} & \mathrm{Da} & \mathrm{Na} & \mathrm{Su}
\end{array}
\end{aligned}
$$

Fig. 3. Raras Pèlog Kempyung Line

(Source: Koesoemadinata 1969: 52) 4.

On each gembyangan, the seven raras form the raras scale which structured as shown in Figure

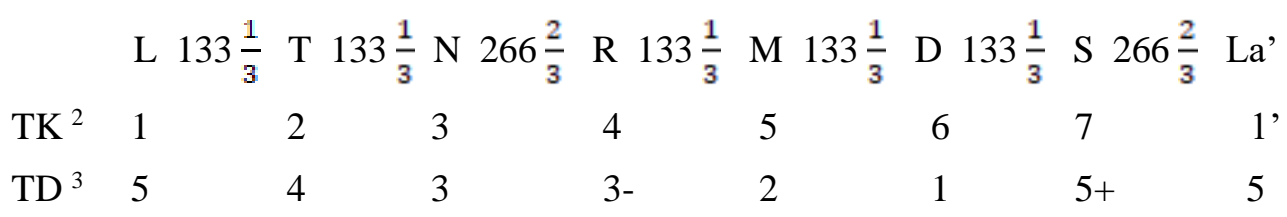

Fig. 4. Structure of Raras Scale in One Gembyang

(Source: Koesoemadinata $1969: 52$ )

Explanation:
$\mathrm{L}=\mathrm{La}$
$\mathrm{M}=\mathrm{Mi}$
$\mathrm{T}=\mathrm{Ti}$
$\mathrm{D}=\mathrm{Da}$
$\mathrm{N}=\mathrm{Na}$
$\mathrm{S}=\mathrm{Su}$
$\mathrm{R} \quad=\mathrm{Ri}$
$\mathrm{La}^{\prime}=$ La High Octace

Because having the same interval on every tone, the nine tones rakitan pèlog can be $1(d a)$, on the other word it has nine surupan. Whereas, the nine tones in rakitan pèlog are divided into Tugu, Sorog, Pamiring, Singgul, Galimer, Panelu, Panangis, Bungur, and Loloran. Two tones from the nine tones on rakitan pèlog as mentioned earlier, which are Panangis and Pamiring, is not exist on gamelan. Thus, he states that there are three surupan on laras pèlog, which include:

\section{Surupan Liwung / Pèlog Liwung ( $\mathrm{da}=$ Galimer) \\ 2. Surupan Djawar/ Pèlog Djawar (da=Tugu/ Barang) \\ 3. Surupan Sorog/Pèlog Sorog $(\mathrm{da}=$ Panelu $)$}

(Source: Koesoemadinata, n.d: 15)

Besides, on his other book, R. M. A. Koesoemadinata also mentions the interval composition on the nine tones laras pèlog on the following Figure 5:

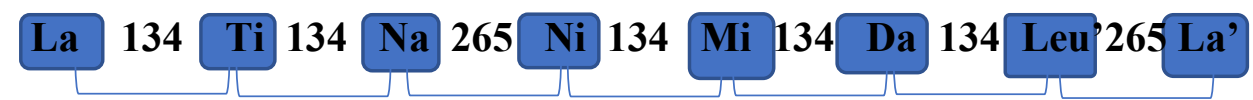

Fig. 5. Interval Composition of the Nine Notes Laras Pèlog

Interval $133 \frac{1}{3}$ sen is rounded up to be 134 sen, Interval $266 \frac{2}{3}$ sen is rounded down to be 265 sen, The difference between $133 \frac{1}{3}$ sen with 134 sen is meaningless, and the difference between $266 \frac{2}{3}$ sen with 265 sen is meaningless (Koesoemadinata 1969: 61). Based on the interval composition number above, assisted with the attached explanation, it is found that the small different number in $133 \frac{1}{3}$ with 134 is meaningless. Hence, it also occurs with the different number between $266 \frac{2}{3}$ with 265. In this case, the reseracher uses interval composition of laras pélog which its interval is $133 \frac{1}{3}$

\footnotetext{
${ }^{2} \mathrm{~K}$ is an acronym used by R. M. A Koesoemadinata and it is not explained further about its actual meaning. However, after discussed it with some people, such as with Priadi Dwi Hardjito, it is assumed that TK is an acronym of Teknik Kepatihan, which is a notation system in Javanese Karawitan.

${ }^{3}$ In line with TK, TD is also an acronym used frequently by R. M. A. Koesoemadinata, that its actual meaning has not been found yet. Nonetheless, having discussed it with Dika Dzikriawan, the writer assumes that TD is an acronym from Teknik Daminatila, which is a notation system used in Sundanese karawitan.
} 
as a result number from dividing 1200 sen as the number of interval in one gembyang by nine as the number of the nine tones laras pélog.

Furthermore, R. M. A. Koesoemadinata argues that playing waditra rebab and singing have different laras feel. It is because playing rebab and singing laras pélog are usually diembat. Hence, the result of its interval is deviate from laras pélog as mentioned earlier. The interval of laras pélog in playing rebab and singing is sometimes enlarged up to 150 sen, and reduced until 120 sen or less (Koesoemadinata 1969: 83).

Embat laras pélog on rebab and singing are various. It is affected by the laras feel from each artists, such as the rebab players or singers (pasinden, ronggeng, tledek dalang and wiraswara). There are two embat on laras pélog that is usually played in rebab and song as shown in Figure 6 and Figure 7.

\section{Laras Pélog Embat Malang}

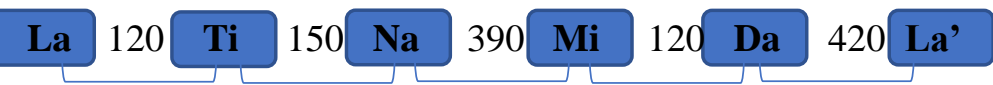

Fig. 6. Scheme of Laras Pélog Embat Malang

\section{Laras Pélog Embat Miring}

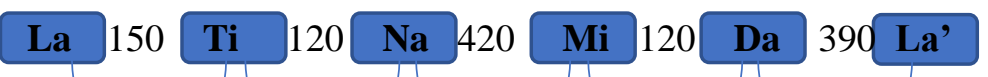

Fig. 7. Scheme of Laras Pélog Embat Miring

(Source: Koesoemadinata 1969: 83)

Both embat laras pélog above are only used in playing rebab and singing accompanied by gamelan music. Meanwhile, in playing rebab and singing without accompanied by gamelan, the resulted interval structure will be different, which is in line with the following statement (Koesoemadinata 1969: 83), "However, if rebaban and singing are only accompanied by waditra for wirama, for instance as in gending kemanak or in gending ketuk tilu, or without accompagnement at all, such as in sekar matjapat, then rebab and singer, if they have to present a song in raras Pélog, usually play and sing in raras or pasijeupan", which its structure can be describe as shown in Figure 8.

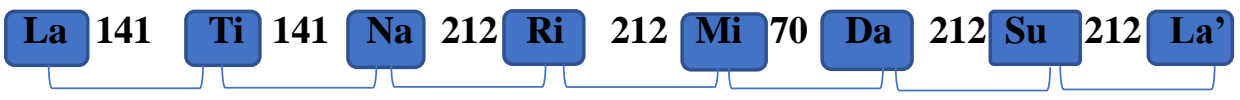

Fig. 8. Interval Structure of Laras Pélog in Playing Rebab and Singing Without Gamelan

(Source: Koesoemadinata 1969: 83)

If the interval structure above is examined, it will be found several numbers which are also contain in interval structure of laras saléndro, degung, and madenda. The number are 212, which exists in laras saléndro, degung and madenda, 424 and 70 which are found in laras degung and madenda. The odd number is only 141 , which is only found in rakitan 17 tones by R. M. A. Koesoemadinata. Because its difference with the nine notes rakitan pélog as what stated by R. M. A. Koesoemadinata, therefore, the interval structure as mentioned above is called as the true laras pélog or sejatining laras pélog, that is laras, which its note in 4 (Ti) is enlarged up to 71 sen (Koesoemadinata 1969: 84).

Having observed the interval structure of laras pélog above, and compared it with the interval structure of the other laras, it is found that every laras in Sundanese karawitan has different interval (note distance), which in turn can emerge exclusive characteristics on each laras. Interval or in Sundanese karawitan is known as swarantara is the height difference between two tones which in the other words is known as srutianada-jarak (Koesoemadinata 1969: 14).

There are several interval terms in Sundanes as those in western music, such as tanpantara, nyampar, adu manis, adu laras, kempyung, adu sari, salah gumun, and gembyang (Hardjito 1982: 26). Those intervals have their own positions on either laras pèlog or saléndro. Table 1 shows the interval terms (swarantara) in laras pèlog according to R. M. A. Koesoemadinata. 
Table 1. Swarantara Laras Pélog

\begin{tabular}{|c|c|c|}
\hline Swarantara term & Explanation & Example \\
\hline Tanpantara & Same note & 1 to 1,2 to 2 , etc \\
\hline Nyampar & Swarantara $\frac{1}{9}$ gembyang & 1 to 2,2 to 3 , etc \\
\hline Adumanis-Alit & Swarantara $\frac{2}{9}$ gembyang & 1 to $3-, 2+$ to 4 , etc \\
\hline Adumanis -Ageung & Swarantara $\frac{3}{9}$ gembyang & 2 to 3,1 to 5 \\
\hline Aduraras & Swarantara $\frac{4}{9}$ gembyang & 1 to 3.2 to 4 \\
\hline Kempyung & Swarantara $\frac{5}{9}$ gembyang & 1 to 4,2 to 5 \\
\hline Adusari-Alit & Swarantara $\frac{6}{9}$ gembyang & 1 to 5,3 to 2 \\
\hline Adusari-Ageung & Swarantara $\frac{7}{9}$ gembyang & $5^{\prime}$ to 3 \\
\hline Salah-gumun & Swarantara $\frac{8}{9}$ gembyang & $5^{\prime}$ to $4,4^{\prime}$ to 3 \\
\hline Gembyang & Swarantara $\frac{9}{9}$ gembyang & 1 to $1^{\prime}, 2$ to $2^{\prime}$ \\
\hline
\end{tabular}

(Source: Koesoemadinata, n.d: 45)

Meanwhile, based on another explanation, the interval terms in laras pélog include in Table 2

Table 2. Swarantara Laras Pélog

\begin{tabular}{|c|c|c|}
\hline Sum of note between two notes & Example & Term \\
\hline Same note & Between note 1 with note & Tanpantara \\
\hline Between two notes, no other notes & Between note 1 with note 2 & Nyampar \\
\hline $\begin{array}{l}\text { Between two notes, separated by one } \\
\text { note }\end{array}$ & Between note 1 with note 3 - & Adu Manis \\
\hline $\begin{array}{c}\text { Between two notes, separated by two } \\
\text { notes }\end{array}$ & Between note 1 with note 3 & Adu Laras \\
\hline $\begin{array}{c}\text { Between two notes, separated by three } \\
\text { notes }\end{array}$ & Between note 1 with note 4 & Kempyung \\
\hline $\begin{array}{c}\text { Between two notes, separated by four } \\
\text { note s }\end{array}$ & Between note 1 with note 5 & Adu Sari \\
\hline $\begin{array}{c}\text { Between two notes, separated by five } \\
\text { notes }\end{array}$ & Between note 1 with note $5+$ & Salah Gumun \\
\hline $\begin{array}{c}\text { Between two notes, separated by six } \\
\text { notes }\end{array}$ & Between note 1 with note 1 ' & Gembyang \\
\hline
\end{tabular}

(Source Palgunadi 2002: 460)

From the two arguments above related to the terms of swarantara in laras pélog, this study uses the terms of swantara as stated by Bram Palgunadi (Palgunadi 2002: 460). It is choosen based on several considerations, such as its more general and common usage, as well as the researcher's learning experience in karawitan department of ISBI Bandung, especially while learning the accoustic subject.

Without neglecting the process of analyzing the data, this study uses six swantara only for five main tones in calculating the data. It is because the reseracher finds a calculating method which compares laras pélog by only using five frequency data from five main tones from a book entitiled Tone Measuremenrs Of Outstanding Javanese Gamelans in Yogyakarta and Surakarta which is arranged in 1972. This book generally summarizes the result of calculating the similarity between laras pélog and saléndro in reality on the field and Machjar's pattern as well as Surakarta's pattern, which concludes that Machjar's pattern posesses the more ideal similarity percentage.

\subsection{Tone Measurement on Sari Oneng Parakansalak Gamelan}

This section describes the result of measuring laras on Sari Oneng Parakansalak gamelan which is obtained by the researcher through field observation. The following are the frequency data from each tone on waditra-waditra as the result of measurement by using Da Tuner Lite application. The 
results of measuring laras on saron waditra using Da Tuner Lite application is described on the Table 3 .

Table 3. Frequency Data and Interval of the $1^{\text {st }}$ Saron

\begin{tabular}{cccc}
\hline Tone Name & $\begin{array}{c}\text { Measured Frequency } \\
(\mathbf{H z})\end{array}$ & $\begin{array}{c}\text { Interval } \\
\text { (sen) }\end{array}$ & Explanantion \\
\hline Singgul (5) & 548,2 & 0 & $5-5$ \\
\hline Galimer (4) & 587,2 & 118.979568 & $4-5$ \\
\hline Panelu (3) & 649,8 & 294.3520986 & $3-5$ \\
\hline Bungur (3-) & 736,2 & 510.4745059 & $(3-)-5$ \\
\hline Loloran (2) & 816,3 & 689.276555 & $2-5$ \\
\hline Barang (1) & 868,8 & 797.18613 & $1-5$ \\
\hline Sorog (5+) & 977,3 & 1000.918996 & $(5+)-5$ \\
\hline
\end{tabular}

Meanwhile, based on another waditra saron, the results of measuring laras using Da Tuner Lite application include in Table 4.

Table 4. Frequency Data and Waditra Interval of the $2^{\text {nd }}$ Saron

\begin{tabular}{cccc}
\hline Tone Name & $\begin{array}{c}\text { Measured Frequency } \\
(\mathbf{H z})\end{array}$ & $\begin{array}{c}\text { Interval } \\
(\mathbf{s e n})\end{array}$ & Explanantion \\
\hline Singgul (5) & 549,6 & 0 & $5-5$ \\
\hline Galimer (4) & 589,9 & 122.506086 & $4-5$ \\
\hline Panelu (3) & 650,2 & 291.0018622 & $3-5$ \\
\hline Bungur (3-) & 735,5 & 504.4120048 & $(3-)-5$ \\
\hline Loloran (2) & 816,5 & 685.285058 & $2-5$ \\
\hline Barang (1) & 869,5 & 794.1648281 & $1-5$ \\
\hline Sorog (5+) & 975,2 & 992.7793462 & $(5+)-5$ \\
\hline
\end{tabular}

The last for waditra saron, the results of measuring laras using Da Tuner Lite application include in Table 5 .

Table 5. Frequency Data and Waditra Interval of the $3^{\text {rd }}$ Saron

\begin{tabular}{cccc}
\hline Tone Name & $\begin{array}{c}\text { Measured Frequency } \\
(\mathbf{H z})\end{array}$ & $\begin{array}{c}\text { Interval } \\
(\mathbf{s e n})\end{array}$ & Explanantion \\
\hline Singgul (5) & 549,7 & 0 & $5-5$ \\
\hline Galimer (4) & 587,8 & 122.1911157 & $4-5$ \\
\hline Panelu (3) & 650,4 & 291.2193336 & $3-5$ \\
\hline Bungur (3-) & 735,2 & 503.3907447 & $(3-)-5$ \\
\hline Loloran (2) & 814,5 & 680.7242633 & $2-5$ \\
\hline Barang (1) & 867,8 & 790.4617281 & $1-5$ \\
\hline Sorog (5+) & 977,8 & 997.0739112 & $(5+)-5$ \\
\hline
\end{tabular}

The results of measuring laras on waditra demung using Da Tuner Lite application is described on the Table 6.

Table 6. Frequency Data Frekuensi and Waditra Demung Interval

\begin{tabular}{cccc}
\hline Tone Name & $\begin{array}{c}\text { Measured Frequency } \\
(\mathbf{H z})\end{array}$ & $\begin{array}{c}\text { Interval } \\
(\mathbf{s e n})\end{array}$ & Explanantion \\
\hline Singgul (5) & 278,9 & 0 & $5-5$ \\
\hline Galimer (4) & 298,5 & 117.5795965 & $4-5$ \\
\hline Panelu (3) & 325,5 & 267.4915308 & $3-5$ \\
\hline Bungur (3-) & 367,8 & 479.0082545 & $(3-)-5$ \\
\hline Loloran (2) & 407,3 & 655.612656 & $2-5$ \\
\hline Barang (1) & 434,2 & 766.3341499 & $1-5$ \\
\hline Sorog (5+) & 484,5 & 956.0984775 & $(5+)-5$ \\
\hline
\end{tabular}


The results of measuring laras on waditra bonang using Da Tuner Lite application include in the Table 7.

Table 7. Bonang Frequency Data and Waditra Bonang Interval

\begin{tabular}{cccc}
\hline Tone Name & $\begin{array}{c}\text { Measured Frequency } \\
(\mathbf{H z})\end{array}$ & $\begin{array}{c}\text { Interval } \\
(\mathbf{s e n})\end{array}$ & Explanantion \\
\hline Singgul (5) & 274,7 & 0 & $5-5$ \\
\hline Galimer (4) & 306,3 & 188.5061478 & $4-5$ \\
\hline Panelu (3) & 328,6 & 310.1706838 & $3-5$ \\
\hline Bungur (3-) & 383,2 & 576.2887808 & $(3-)-5$ \\
\hline Loloran (2) & 406,3 & 677.626145 & $2-5$ \\
\hline Barang (1) & 439,9 & 815.182429 & $1-5$ \\
\hline Sorog (5+) & 491,4 & 1006.849137 & $(5+)-5$ \\
\hline
\end{tabular}

The results of measuring laras on waditra rincik as the last sample waditra using Da Tuner Lite application include in the Table 8.

Table 8. Frequency Data and Waditra Rincik Interval

\begin{tabular}{cccc}
\hline Tone Name & $\begin{array}{c}\text { Measured Frequency } \\
(\mathbf{H z})\end{array}$ & $\begin{array}{c}\text { Interval } \\
(\mathbf{s e n})\end{array}$ & Explanantion \\
\hline Singgul (5) & 551,8 & 0 & $5-5$ \\
\hline Galimer (4) & 613,7 & 184.0657521 & $4-5$ \\
\hline Panelu (3) & 657,3 & 302.887834 & $3-5$ \\
\hline Bungur (3-) & 740,9 & 510.1600524 & $(3-)-5$ \\
\hline Loloran (2) & 824,7 & 695.6687411 & $2-5$ \\
\hline Barang (1) & 866,4 & 781.0653435 & $1-5$ \\
\hline Sorog (5+) & 986,5 & 1005.808313 & $(5+)-5$ \\
\hline
\end{tabular}

The last, Table 9 includes the results of measuring laras from average all the samples waditra using Da Tuner Lite Application.

Table 9. Result Data of Average Measurement

\begin{tabular}{ccc}
\hline Tone & Sum & Average \\
\hline Singgul & 3306.5 & 551.083 \\
\hline Galimer & 3570.2 & 595.033 \\
\hline Panelu & 3915.9 & 652.65 \\
\hline Bungur & 4449.8 & 741.633 \\
\hline Loloran & 4899.2 & 816.533 \\
\hline Barang & 5220.7 & 870.116 \\
\hline Sorog & 5868.6 & 978.1 \\
\hline Singgul' & 6613 & 1102.166
\end{tabular}

\subsection{Laras Similarity Percentage}

This section is the main point of this research. It involves observation and analysis of the data obtained from measurement.

\subsubsection{Sari Oneng Parakansalak Gamelan Measurement Result of Jaap Kunst by using Theory of Laras Pélog by R. M. A. Koesoemadinata}

The following is presented the tone frequency data of Sari Oneng Parakansalak gamelan by Jaap Kunst in 1949 which is written in a book entitled "Music In Java" (Kunst 1949:573). The measuring data as the result of measuring laras by Jaap Kunst is describe detaily on the Table 10. 
Table 10. Frequency Data of Sari Oneng Parakansalak Gamelan

\begin{tabular}{cccc}
\hline Tone & $\begin{array}{c}\text { Measured } \\
\text { Frequency by } \\
\text { Jaap Kunst }\end{array}$ & Embat Machjar & Interval \\
\hline Singgul & $266 \mathrm{~Hz}$ & Tanpantara & 0 \\
\hline Galimer & $289,5 \mathrm{~Hz}$ & Nyampar & 146,564523 \\
\hline Panelu & $317,5 \mathrm{~Hz}$ & Adu Manis & 306.396415 \\
\hline Bungur & $365 \mathrm{~Hz}$ & Kempyung & 547.764262 \\
\hline Loloran & $395 \mathrm{~Hz}$ & Adu Sari & 684.511689 \\
\hline Barang & $430 \mathrm{~Hz}$ & Adu Laras & 831.492497 \\
\hline Sorog & $479,5 \mathrm{~Hz}$ & Salah Gumun & 1020.12548 \\
\hline Singgul & $532 \mathrm{~Hz}$ & Gembyang & 1200 \\
\hline
\end{tabular}

From the Table 10, the similairty level of frequency data and interval from Sari Oneng Parakansalak Gamelan with laras pélog theory by R. M. A. Koesoemadinata can be found. It is presented in form table which is made with Microsoft Excel program by using formula mentioned earlier. There are several columns which are filled with the data, and then calculated by using the following formula:

- Embat Machjar column, consist of the interval terms or swarantara laras pélog, frequency is the data frequency in $\mathrm{Hz}$ (Hertz) which is obtained from the measurement result from the measured waditra.

- Factual data cloumn (f), consists of interval in sen from each measured tones in the field.

- Expected data column (e) is the data interval in laras pélog, such as explained on the earlier laras pélog scheme.

- The calculated data result, which is input on the square chi table, especially on the formula column $\frac{\left(\boldsymbol{f}_{1}-\boldsymbol{e}_{1}\right)^{\wedge} \mathbf{2}}{e_{\mathrm{i}}}$

The table format with the data columns such as explained above, is used in all the process of calculating and analyzing the data in order to find out the laras' similarity level. For more details, the following is the result of data analysis and calculation to figure out the similarity between frequncy and interval from Jaap Kunst's research in 1949 with laras pélog theory by R. M. A. Koesoemadinata. It is presented in form of an image as a result of data convertion from Microsoft Excel as a number processing program used in this research.

Based on the result of a study conducted by Jaap Kunst in 1949, it was found that the frequency struture and interval of Sari Oneng Parakansalak gamelan showed a tendency into laras pélog liwung. It is identified from the data analysis result and calculation, such as implied on the tables provided above, which indicate that $98,2272 \%$ as the highest percentage of similarity level is shown on the calculation of the laras pélog liwung table.

\subsubsection{The Research Result of Sari Oneng Parakansalak Gamelan by Using Laras Pélog Theory by R. M. A. Koesoemadinata}

This section presents the result of data analysis and calculation by using formula mentioned earlier, in form of image converted from Microsoft Excel file. Analayzing the data is conducted by calculating the similarity level of each waditra, and calculating the similarity with the average frequency of all waditra. Calculating the measurement data is conducted in order to find out the more accurate result, for it can detect the waditra which is not suitable for use as a sample.

On contrary, analyzing the data by calculating the average frequency (in one octave or gembyang) of all waditra tends to be unable to detect the improper samples. However, to find out the different calculating result from the two methods above, the following is presented the result of analyzing the data by calculating the similarity level of each waditra, also by calculating the average of all waditra in form of a table in Table 11. 
Table 11. Result of Calculating Analysis of the Similarity Level between Sari Oneng Parakanasalak Gamelan with Laras Pélog Theory by R. M. A. Koesoemadinata

\begin{tabular}{|c|c|c|}
\hline Measured Waditra & Surupan & $\begin{array}{l}\text { Percentage of } \\
\text { similarity }\end{array}$ \\
\hline \multirow[t]{3}{*}{ Measurement result by Jaap Kunst } & Djawar & $64,36 \%$ \\
\hline & Liwung & $98,23 \%$ \\
\hline & Sorog & $38,86 \%$ \\
\hline \multirow[t]{3}{*}{ Saron 1} & Djawar & $80,98 \%$ \\
\hline & Liwung & $69,89 \%$ \\
\hline & Sorog & $32,46 \%$ \\
\hline \multirow[t]{3}{*}{ Saron 2} & Djawar & $87,19 \%$ \\
\hline & Liwung & $76,22 \%$ \\
\hline & Sorog & $44,79 \%$ \\
\hline \multirow[t]{3}{*}{ Saron 3} & Djawar & $75,99 \%$ \\
\hline & Liwung & $75,84 \%$ \\
\hline & Sorog & $27,25 \%$ \\
\hline \multirow[t]{3}{*}{ Demung } & Djawar & $34,26 \%$ \\
\hline & Liwung & $48,56 \%$ \\
\hline & Sorog & $65,83 \%$ \\
\hline \multirow[t]{3}{*}{ Bonang } & Djawar & $45,08 \%$ \\
\hline & Liwung & $9,85 \%$ \\
\hline & Sorog & $35,06 \%$ \\
\hline \multirow[t]{3}{*}{ Rincik } & Djawar & $0,73 \%$ \\
\hline & Liwung & $0 \%$ \\
\hline & Sorog & $16,332 \%$ \\
\hline \multirow{3}{*}{$\begin{array}{l}\text { The average of all measured } \\
\text { Waditra }\end{array}$} & Djawar & $73,73 \%$ \\
\hline & Liwung & $92,4 \%$ \\
\hline & Sorog & $41,24 \%$ \\
\hline
\end{tabular}

From the result above, the red percentage numbers refer to the measurement result which includes in the ideal chategory of calculation. The ideal chategory in this context is not an absolute because musically, there are number of terms which are described using the word relative as adjective is an implication of reality that sometimes something can only be expressed when it is in connection with its ambience (Wisuttipat $2015: 189$ ).

The highest similarity level $(87,19 \%)$ is on waditra saron two surupan djawar. The three measured waditra saron tend to show the identical result that they have pélog djawar laras. While for the other three waditra, which are demung, bonang and rincik, are considered to be inappropriate to use as samples. The inappropriateness of those waditra is discovered form the sound produced during the measuring process. It also can be seen from the resulted percentage numbers, that are not prominent and they do not reach $75 \%$, which is the ideal percentage of similarity level.

\subsubsection{The Research Result of Sari Oneng Parakansalak Gamelan by Using Laras Degung Theory by R. M. A Koesoemadinata}

As what stated in the background of this research, besides answering the laras system of Sari Oneng Parakansalak gamelan and its similarity with laras pélog by R. M. A Koesoemadinata, this research is also able to give guidance and answer related to the issue which is still discussed among the society who still hesitate the existence of Sundanese pélog gamelan. The opinion about Sundanese pélog gamelan, which its existence is still hesitated, develops in accordance with the number of artists or society in general who use different terms for pélog gamelan. Koko Koswara, a well known Sundanese artist, oriented on kacapi playing mentions laras pélog as pélog degung. In line with this, Nano S in Sundanese Newspaper 181 edition, page 10 also states:

"Nu janten masalah saleresna mah sanés antar pribadina, namung pasalia paham soal istilah. Pa Koko anu oriéntasina kana kacapi, nu berkembang di masarakat, nyebatkeun pélog degung. Sedeng Pa Machyar, antawis pélog sareng degung téh bénten pisan, 
dumasar kana tiori anjeuna anu oriéntasina kana gamelan. Masalahna téh béda panginditan. Mang Koko dumasar kana kanyataan, yén di masarakat upama ngalaras/ nyétem laras pélog dina kacapi, swarantara sora na (3) sareng ti (4) téh renggang." (Nano S, n.d: 10)

Translate:

"The actual problem between R.M.A Koesoemadinata with Pa Koko is not about personal but in using terms in laras. Based on kacapi as Koko's orientation, most of Sundanese people using pelog degung. Furthermore, R. M. A. Koesoemadinata distinguishes the use of the term Pelog and Degung based on the discovery of his laras theory with the gamelan orientation. The difference comes from the different background. Mang Koko's statement is based on his discovery in the practice in the field where the scale of tone between 3 and 4 is far apart"

From the quotation above, it is found that the term of pélog degung used by Koko Koswara can only be proven through the process of pelarasan kacapi. Meanwhile, the recent process of pelarasan in Sundanese art instruments only rely on laras feel from each artist. However, in science and academic field, feeling is a very relative standard and thus can not be determined as a standard in discussing a theory or a phenomenon occured in the society. Koko Koswara's assumption, which is based on kacapi playing, in fact affects some people's comprehension. It is possible, because Koko Koswara is a famous and influential figure in Sundanese Karawitan (especially as the creator of Wanda Anyar ${ }^{4}$ ) both as practitioner artist and as academic artist.

However, in order to solve the problems and phenomena occured in the society, a theory that can be used to analyze the data is needed so that the expected result can be produced. Based on that assumption, the researcher uses laras degung theory by R. M. A. Koesoemadinata as an isntrument to answer the assumptions mentioned earlier. There are several reasons which underly the selection of that theory. First, it has the definite knowledge base. Besides, it is still used as the only basic theory of laras in Sundanese karawitan until nowadays.

In the book entitled Seni Raras, R. M. A Koeseomadinata refers to the result of a research he conducted in 1942, at which he presented two kinds of laras degung which derive from 15 tones rakitan saléndro and 10 tones rakitan saléndro to his uncle named Raden Emung Purawinata. According to his uncle, laras degung whoich derives from 15 tones rakitan saléndro is more mardawa atau more melodious. The following is the interval composition or swarantara laras degung which derives from the 15 tones rakitan saléndro (Figure 9).

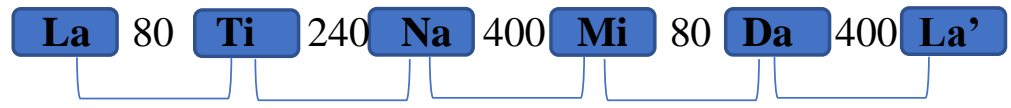

Fig. 9. Laras Degung from the 15 tones Rakitan Saléndro

(Source: Koesoemadinata 1969: 32)

Moreover, still on the same book, R. M. A. Koeseomadinata mentions laras degung sedjati which is resulted from 17 tones rakitan saléndro inspired by rebab playing by Madjasik when playing a songg entitled Banjar Sinom from laras madenda 9 tones (Herdini, 2004: 60). Then, the laras madenda 9 tones is developed by increasing and decreasing the tones by half, so it forms 17 tones rakitan laras 17 which the interval of each tone is $70 \frac{10}{17}$ sen. In 17 tones rakitan saléndro, there is an interval composition or swarantara laras degung as shown in Figure 10.

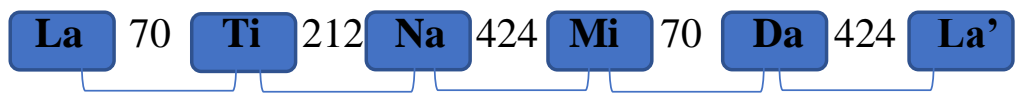

Fig. 10. Laras Degung from 17 tones Rakitan saléndro

(Source: Koesoemadinata 1969: 79)

Both interval composition or swarantara laras degung above is then called as expected data (e), which is compared with factual data (f) that is data result from measuring the appropriate samples from waditra-waditra Sari Oneng Parakansalak gamelan. The intended data then is re-calculated to

\footnotetext{
${ }^{4}$ A musical genre in Sundanese Karawitan.
} 
find out the percentage of similarity level with the interval composition of laras degung in order to answer the research problems.

Based on the scheme, it can be said that the data calculation and analysis result in finding the similarity level of the waditra samples of Sari Oneng Parakansalak gamelan with laras degung theory by R. M. A. Koesoemadinata reveals the relatively same result. All of the final numbers can not be input into square chi table, because they are too big. Hence, it can be concluded that the laras similarity percentage is less than $0,1 \%$. The number is certainly too far from the ideal similarity level. In conclusion, Sari Oneng Parakansalak gamelan is not laras degung gamelan. It is based on the comparison with laras degung theory by R. M. A. Koesoemadinata, either laras degung which dreives from 15 tones rakitan saléndro or 17 tones rakitan saléndro. On the other words, it is certained that Sari Oneng Parakansalak gamelan does not include into laras degung or pélog degung. This finding can be a hint as well as a supporting evidence of Sundanese pélog gamelan existence.

\section{Conclusion}

The conclusion of this research is presented in form of laras scheme in order to find out the laras system of Sari Oneng Parakansalak gamelan. It provides the measurement result conducted by the researcher, which includes the measurement result and the percentage of laras similarity level from both each waditra and the average from all waditra by employing laras theory by R. M. A. Koesoemadinata. In accrodance with the reality faced by researcher in the field, it is believed that the calculation of each waditra is more precise, rather than the calculation the average of all waditra laras.

Therefore, it can be concluded that Sari Oneng Parakansalak gamelan, is a laras pélog gamelan. It is confirmed with its percentage of similarity level with laras pélog theory by R. M. A. Koesoemadinata, which is on the three analyzed waditra saron, is more than $75 \%$. The analysis result is also a strong evidence about the existence of Sundanese pélog gamelan which is often questioned by Sundanese people.

\section{References}

Creswell, John. W. 2016. Research Design, Qualitative, Quantitative and Mixed Methods. Yogyakarta: Pustaka Pelajar.

Creswell John W. 2018. Research Design Pendekatan Metode Kualitatif, Kuantitatif, Dan Campuran, Edisi 4. Yogyakarta: Pustaka Pelajar.

Ellis, Alexander J. 1885. "On the Musical Scale of Various Nations." International Journal of The Society of Arts XXXIII (1.683).

Hardjito, Priadi Dwi. 1982. "Etnomusikologi \& Filsafat Nada.” ASTI Bandung.

Herdini, Heri. 2004. "Peninjauan Ulang Terhadap Teori Laras Dan Surupan Karya Raden Machjar Angga Koesoemadinata." Panggung XXXII: 54-66.

Hermawan, Deni. 2001. "Tangga Nada Musik Sunda: Antara Kenyataan Teoritis Dan Praktis.” Panggung XXI: 71-90.

Koesoemadinata, R.M.A. n.d. Ringkesan Pangawikan Rinengga Swara. Jakarta: Noordhoff - Kolff N. V. 1969. Ilmu Seni Raras. Jakarta: Pradjaparamita.

Kunst, Jaap. 1949. Music in Java: Its History, Its Theory and Its Technique. Springer.

Nano S. n.d. "Mang Koko Juru Sanggi Nu Masagi 4.” Sunda Newspaper.

Palgunadi, Bram. 2002. Serat Kandha Karawitan Jawi: Mengenal Seni Karawitan Jawa. Penerbit ITB.

Wisuttipat, Nattapol. 2015. "Relative Nature of Thai Traditional Music through Its Tuning System." International Journal of Creative and Arts Studies 2 (1): 189-99. 